\title{
Minimization of adverse environmental effects of a sports complex through implementation of green management
}

\author{
M. Abbaspour ${ }^{1}$, A. R. Karbasi ${ }^{2}$ \& S. Khadivi ${ }^{3}$ \\ ${ }^{I}$ Department of Mechanical Engineering, \\ Sharif University of Technology, Tehran, Iran \\ ${ }^{2}$ Iran Energy Efficiency Organization, Tehran, Iran \\ ${ }^{3}$ Center for Environment \& Energy Research and Study (Science \& \\ Research Branch of Islamic Azad University), Tehran, Iran
}

\begin{abstract}
Implementation of green management in sports complexes can ensure the continuous arrangement and assessment of activities from an environmental perspective and will end up with the control and prevention of contaminants. Enghelab Sports Complex in Iran was selected for this study due to its size and long-term activities. The establishment of Enghelab Sports Complex is among important national projects whose framework was founded in the late 1950s. Due to the comprehensive plan of the aforesaid sports complex, numerous centers and departments were established in this site in order to materialize its envisioned sports, recreational and cultural objectives. Green management pursues greater productivity, lower water and energy consumption, reduction of consumed materials like paper, management of solid wastes and creation of a recycling system in Enghelab Sports Complex. This sophisticated complex provides a broad range of sports and recreational services to the residents of Greater Tehran and thus could be considered as a suitable model for similar facilities.
\end{abstract}

Keywords: green management, consumption pattern, environmental quality, sports complex. 


\section{Introduction}

During the past few years, new concepts like Green Management, Green Government, Green University and etc have been introduced in management systems [3]. Taking into account the ever-increasing prominence of environmental management in the world arena, the implementation of green management systems could enhance managerial recommendations as well as improve the preparedness of pertinent organizations to face up to future challenges [5]. Therefore, establishment of a green management system with the cooperation of senior managers and members of the related organizations would pave the way for profound alteration and evolution of executive branches of such institutions [2].

The green management system is considered as a management system, which is entrusted with dynamic and continuous arrangement and assessment of activities and processes from the environmental perspective and to monitor, prevent and control contaminants. According to the ratification of the Council of Ministers dated April $6^{\text {th }} 2003$, green management is considered as a component of the national managerial system and organizations should function based upon the objectives of green management [4]. However, not only are sports complexes are involved with physical education, but they also address cultural, social and recreational aspects. Thus, Enghelab Sports Complex (ESC), as the largest sports complex in the country, is a prominent target for the implementation of green management in sport facilities. The successful implementation of such a system in the above-mentioned sports complex could be used as a model for establishment of green management at national and international levels.

\section{Materials and methods}

In the first step, the current status of the Sports Complex in terms of available spaces and buildings; number of personnel; diversity of applications; type and number of fauna and vegetation coverage; level of water, electricity and gas consumption and other related parameters was assessed. Secondly, the environmental and energy status of the complex in terms of water quality, noise, air quality, solid wastes, and energy consumption were studied. Moreover, the other pertinent issues of interest like economic and investment aspects for enhancement of the current status were examined. Finally, after conducting the preliminary measures and the above-mentioned study, the guidelines for establishment of green management system in sports complexes are provided based on four major topics namely, (1) education, dissemination of information and enhancement of personnel awareness; (2) measures for optimization of resource consumption; (3) measures to improve the environmental status of the complex, monitoring and continuous supervision; and (4) preparation and implementation of the guidelines in Enghelab Sports Complex along with a list of managerial and executive recommendations. 


\section{Results}

In order to establish the green management system in ESC, it is necessary to attain adequate familiarity with the sports and recreational activities as well as the environmental status of the complex. Table 1 shows a summary of related information about this sports complex.

Table 1: $\quad$ Specifications of Enghelab Sports Complex.

\begin{tabular}{|c|c|c|}
\hline No. & Specifications & Remark \\
\hline 1 & Number of members in 2003 & 52,083 \\
\hline 2 & Number of employees & 310 \\
\hline 3 & Total area of the complex (Hectares) & 95 \\
\hline 4 & Green coverage area (Hectares) & 70 \\
\hline 5 & Average temperature $1989-1999\left({ }^{\circ} \mathrm{C}\right)$ & 17.7 \\
\hline 6 & $\begin{array}{l}\text { Average annual precipitation 1989-1999 } \\
(\mathrm{mm})\end{array}$ & 245.15 \\
\hline 7 & Number of trees & 23,951 \\
\hline 8 & $\begin{array}{l}\text { Foundation area of the administration } \\
\text { building }\left(\mathrm{m}^{2}\right)\end{array}$ & 2,290 \\
\hline 9 & Number of in-door pools & 3 \\
\hline 10 & Number of tennis courts & 37 \\
\hline 11 & Jurisdiction & $\begin{array}{c}\text { District } 3 \text { of Tehran } \\
\text { Municipality }\end{array}$ \\
\hline
\end{tabular}

In order to determine the environmental status of the complex, eleven stations have been identified to measure the concentration of air pollutants at various time intervals. Figure 1 indicates the location of these stations and Table 2 shows the concentration of major pollutants and the noise levels in the stations.

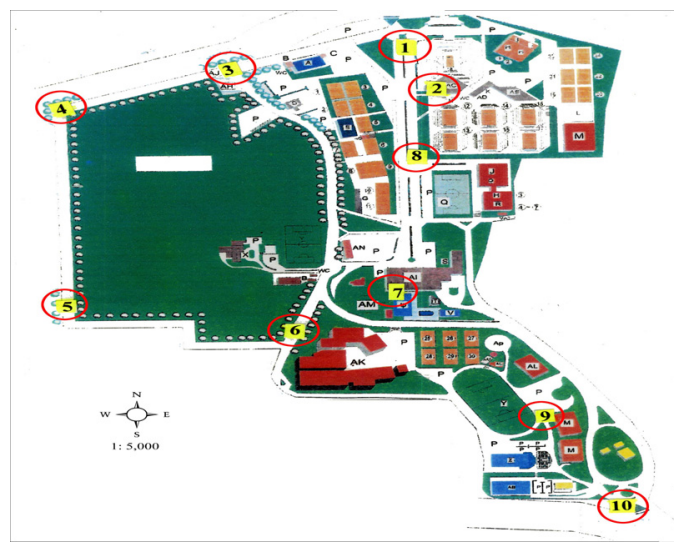

Figure 1: Location of air and noise pollution measurement stations in Enghelab Sports Complex. 
Noise level ranged from 55 to $105 \mathrm{~dB}_{\mathrm{A}}$ with a mean value of $68 \mathrm{~dB}_{\mathrm{A}}$. Obviously the highest ones have been observed in the borders of the complex with adjacent streets.

Table 2: $\quad$ Concentrations of air pollutants at Enghelab sports complex.

\begin{tabular}{|c|c|c|c|c|c|}
\hline $\begin{array}{c}\text { Station } \\
\text { No. }\end{array}$ & $\begin{array}{l}\text { Wind } \\
\text { Speed } \\
(\mathrm{m} / \mathrm{s})\end{array}$ & $\begin{array}{c}\text { Number of } \\
\text { Suspended } \\
\text { Particulate Matter } \\
\left(\mathrm{m} \text { No. Per } \mathrm{m}^{3}\right)\end{array}$ & $\begin{array}{c}\mathrm{CO} \\
\text { Concentration } \\
(\mathrm{ppm})\end{array}$ & $\begin{array}{l}\mathrm{NO} \\
\text { Concen } \\
\text {-tration } \\
(\mathrm{ppm}) \\
\end{array}$ & $\begin{array}{c}\text { Leq } \\
\left(\mathrm{dB}_{\mathrm{A}}\right)\end{array}$ \\
\hline 1 & 0.49 & 261.53 & 2.5 & 1 & 68.7 \\
\hline 2 & 0.38 & 80.09 & 5.5 & 2.5 & 69.1 \\
\hline 3 & 0.74 & 91.39 & 4.5 & 1.5 & 69 \\
\hline 4 & 0.34 & 141.50 & 11 & 0.5 & 70.3 \\
\hline 5 & 0.45 & 345.22 & 4 & 0 & 69.8 \\
\hline 6 & 1.16 & 111.23 & 2 & 0 & 69.5 \\
\hline 7 & 0.5 & 89.27 & 2 & 0 & 69.3 \\
\hline 8 & 0.7 & 81.96 & 3 & 0 & 69.3 \\
\hline 9 & 1.61 & 81.01 & 2 & 0 & 67.7 \\
\hline 10 & 0.5 & 82.03 & 5 & 0 & 71.5 \\
\hline 11 & 0 & 183.95 & 24 & 1.5 & 77.8 \\
\hline Min. & 0 & 80.09 & 2 & 0 & 65 \\
\hline Max. & 1.6 & 345.22 & 24 & 2.5 & 77.8 \\
\hline Mean & 0.62 & 140.83 & 5.9 & 0.6 & 72 \\
\hline
\end{tabular}

Numerous visits were made to the complex during different seasons of the year with the intention of determining the status of the produced solid waste (garbage) production in ESC through the identification of solid waste ingredients and the applied management schemes for their collection, transportation and disposal. Manual separation and weighing of the solid waste were conducted to identify the qualitative status of the produced garbage, the results of which are shown in Table 3.

Table 3: Status of solid waste production (type and amount) in the complex.

\begin{tabular}{|l|c|c|c|c|c|c|}
\hline Material & Plastic & $\begin{array}{c}\text { Putresciable } \\
\text { Materials }\end{array}$ & Glass & Paper & Metal & $\begin{array}{c}\text { Total } \\
\text { Solid } \\
\text { Waste } \\
\text { Produced } \\
\text { Annually }\end{array}$ \\
\hline $\begin{array}{l}\text { \% of Produced } \\
\text { Solid Waste }\end{array}$ & 24.1 & 45.9 & 7.6 & 19.3 & 3.1 & 100 \\
\hline $\begin{array}{l}\text { Weight of } \\
\text { Produced Solid } \\
\begin{array}{l}\text { Waste } \\
\text { (Tons)/Yr. }\end{array}\end{array}$ & 131.40 & 250.75 & 41.61 & 105.12 & 16.97 & 545.86 \\
\hline
\end{tabular}


A review of the water and electricity bills was made with the aim of assessing the water and energy consumption of the Complex the results of which are presented in Table 4.

Table 4: $\quad$ Water and energy consumption in Enghelab Sports Complex.

\begin{tabular}{|l|c|c|c|c|c|}
\hline Time & Spring & Summer & Autumn & Winter & $\begin{array}{c}\text { Whole } \\
\text { Year }\end{array}$ \\
\hline $\begin{array}{l}\text { Water } \\
\text { Consumption } \\
\text { (Cubic Meters) }\end{array}$ & 303.9 & 2904.1 & 1131 & 110 & 4449 \\
\hline $\begin{array}{l}\text { Energy } \\
\text { Consumption } \\
(\text { Kwh })\end{array}$ & 1294191 & 1322161 & 1550142 & 1659070 & 5825564 \\
\hline
\end{tabular}

The status of the administrative building from the energy consumption perspective was studied with the purpose of assessing the potentials for energy conservation in that facility. The aforesaid building was selected as the model for the preliminary auditing. Therefore, electrical appliances in the administrative building were identified and it was found that fan coils consume the highest electricity (744 Kwh/month).

The opinions of managers, personnel and members of the Sports Complex are quite useful in proper preparation of the desired management system. Thus, due to the considerable number of members and their related issues, it was decided to prepare a questionnaire and ask 50 members and 50 personnel to fill it out in order to facilitate the proper establishment of green management.

\section{Discussion and conclusion}

As a result of the conducted studies on the environmental quality of the complex, the consumption pattern of water and energy, and the production of solid waste, the following conclusions were reached.

The air quality in the city of Tehran is dependent on the air pollution and its stability. Thus, based on the conducted measurements, the stations adjacent to Seoul and Neayesh Expressways with heavy traffic congestion registered higher levels of air pollution. For this reason, stations No.11 and No.4 registered the highest levels of CO (10.3 ppm and $24 \mathrm{ppm})$. On the other hand, stations No.2, No.3 and No.11 had the highest levels of NO, registering $2.5 \mathrm{ppm}, 1.7 \mathrm{ppm}$ and 1.5 ppm, respectively. Moreover, stations No.11 and No.4 with the highest levels of suspended particulate matter showed $5.2 \times 10^{6}$ and $4 \times 10^{6}$ levels. It is important to point out that most of the registered levels exceeded the permissible standard [1]. The CO levels in stations 11 and 4 surpassed the standard limit of 9 ppm, which indicates the need for remedial measures. Meanwhile, the level of suspended particulate matter in the aforesaid stations went beyond the standard range of suspended particulate matter in clean air (from $200 \times 1000$ to $1000 \mathrm{x}$ 1000 , number of particulate matter per cubic foot of air). It seems that the status 
of the air pollution in the Complex is destined to follow the pollution pattern of Tehran [1].

Therefore, reduction of energy consumption in the administrative building was identified (as shown in Table 5).

Table 5: Reduction of energy consumption in the administrative building.

\begin{tabular}{|c|c|c|c|c|}
\hline Vo. & Activities & $\begin{array}{c}\text { Power } \\
\text { Consumption } \\
\text { (Present } \\
\text { Condition) } \\
\text { (Kwh/month) }\end{array}$ & $\begin{array}{c}\text { Power } \\
\text { Consumption } \\
\text { (Modified } \\
\text { Condition) } \\
\text { (Kwh/month) }\end{array}$ & $\begin{array}{l}\text { Energy Saving } \\
\text { (Kwh/month) }\end{array}$ \\
\hline 1 & $\begin{array}{l}\text { Substitution of light bulbs } \\
\text { with low energy consumption } \\
\text { brands ( } 110 \text { bulbs) }\end{array}$ & 712.8 & 256.4 & 256.4 \\
\hline 2 & $\begin{array}{lllr}\begin{array}{l}\text { Proper } \\
\text { systems }\end{array} & \text { use } & \text { of } & \text { lighting } \\
\text { timer) } & & & \\
\end{array}$ & 1782 & 891 & 891 \\
\hline 3 & $\begin{array}{l}\text { Substitution of } r \text { old } \\
\text { refrigerators with more } \\
\text { efficient ones (standard } \\
\text { labeled refrigerators) (24 } \\
\text { refrigerators) }\end{array}$ & 257.04 & 216 & 41.04 \\
\hline 4 & $\begin{array}{l}\text { Reduction of the number of } \\
\text { existing computers and their } \\
\text { proper use ( } 16 \text { computers) }\end{array}$ & 624 & 390 & 234 \\
\hline 5 & $\begin{array}{l}\text { Reduction of the number of } \\
\text { existing printers and their } \\
\text { proper use }\end{array}$ & 28.08 & 17.55 & 10.53 \\
\hline 6 & $\begin{array}{l}\text { Substitution of present copier } \\
\text { with star energy labeled } \\
\text { brand }\end{array}$ & 72.8 & 54.6 & 18.2 \\
\hline 7 & $\begin{array}{l}\text { Do not leave TVs unattended } \\
(2 \mathrm{TV})\end{array}$ & 20.8 & 5.2 & 15.6 \\
\hline 8 & $\begin{array}{l}\text { Using the fan-coil system } \\
\text { with thermostat to control } \\
\text { temperature (and stop the } \\
\text { system during closing) }\end{array}$ & 744 & 465 & 279 \\
\hline 9 & $\begin{array}{l}\text { Proper use of ventilator (and } \\
\text { stop the system during } \\
\text { closing) }\end{array}$ & 84 & 52.5 & 31.5 \\
\hline \multicolumn{2}{|c|}{ Total consumption } & 4325.25 & 2348.25 & 1777.27 \\
\hline \multicolumn{4}{|c|}{ Total annual consumption } & 21327.24 \\
\hline
\end{tabular}

At the same time, the utilization of GIS and Arc view software, and introduction of the resultant data and information on the levels of Carbon Monoxide and Particulate Matter made it possible to draw up a graphic map of air pollution and the location of the air and noise measurement stations. These maps are shown in Figures 1, 2 and 3. 


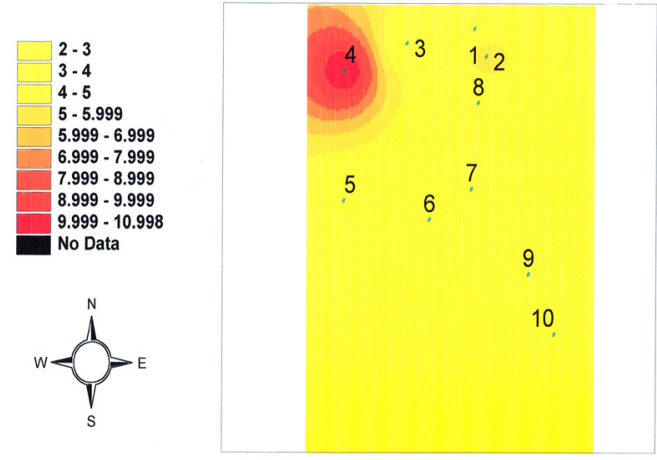

Figure 2: Air pollution map in Enghelab sports complex (carbon monoxide, ppm).

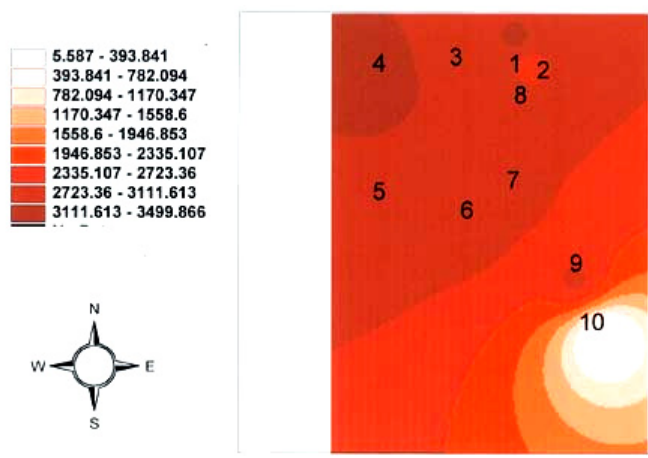

Figure 3: Air pollution map in Enghelab sports complex (suspended particulate matter, $\mathrm{m}$ No. per $\mathrm{m}^{3}$ ).

The noise quality of the Complex exceeds the standard limits most of the time and the lowest registered level "Leq" belongs to station 9 with a value of 67.7 dBA. On the other hand, the highest registered level belongs to station 11 with a value of $77.8 \mathrm{dBA}$. By taking into consideration the noise pollution standard in commercial areas of $65 \mathrm{dBA}$ between $7 \mathrm{am}$ to $10 \mathrm{pm}$ and $55 \mathrm{dBA}$ between $10 \mathrm{pm}$ to $7 \mathrm{am}[1]$, it could be concluded that the noise levels in Enghelab Sports Complex are considerably higher than the permissible limits. This issue becomes more significant, when the instantaneous noise levels of over $105 \mathrm{dBA}$ at the Complex are taken into consideration. The above-mentioned values indicate the need for control and monitoring measures by the pertinent authorities. 
Table 6: Guidelines for promotion of green management in sports complexes.

\begin{tabular}{|c|c|}
\hline Action & Remarks \\
\hline $\begin{array}{l}\text { 1-Training, Dissemination of } \\
\text { information and Enhancement of } \\
\text { Members and Personnel's } \\
\text { Awareness }\end{array}$ & $\begin{array}{l}\text { 1-1- } \begin{array}{l}\text { Providing training on protection of } \\
\text { the environment to the members }\end{array} \\
\text { 1-2- Providing training to the personnel } \\
\text { on protection and preservation of } \\
\text { the environment } \\
1-3-\begin{array}{l}\text { Providing training to the personnel } \\
\text { of the Complex on protection and } \\
\text { preservation of the resources }\end{array}\end{array}$ \\
\hline $\begin{array}{l}\text { 2-Implementation of } \\
\text { Optimization Measures on } \\
\text { Resource Consumption }\end{array}$ & $\begin{array}{l}\text { 2-1- Measures for reduction of water } \\
\text { consumption } \\
\text { 2-2- Practical measures for reduction of } \\
\text { electricity consumption } \\
\text { 2-3- Practical measures for reduction of } \\
\text { the consumption of natural gas } \\
\text { 2-4- Practical measures for reduction of } \\
\text { paper consumption } \\
\text { 2-5- Practical measures for improvement } \\
\text { of energy consumption in heating } \\
\text { and air conditioning systems }\end{array}$ \\
\hline $\begin{array}{c}\text { 3-Measures for Enhancement of } \\
\text { Environmental Conditions of } \\
\text { The Complex }\end{array}$ & $\begin{array}{l}\text { 3-1-Measures for reduction of solid waste } \\
\text { production and separation of garbage } \\
\text { at origin } \\
\text { 3-2- Measures to reduce noise pollution } \\
\text { 3-3- Measures to reduce air pollution } \\
\text { 3-4- Measures to reduce wastewater } \\
\text { production }\end{array}$ \\
\hline $\begin{array}{l}\text { 4-Continuous monitoring and } \\
\text { supervision }\end{array}$ & $\begin{array}{l}\text { 4.1- Monitoring the activities for } \\
\text { optimization of paper, water and energy } \\
\text { consumption } \\
4.2-\text { Monitoring and supervision of } \\
\text { educational training programs and their } \\
\text { proper implementation } \\
4.3-\text { Monitoring and supervision of } \\
\text { environmental quality }\end{array}$ \\
\hline
\end{tabular}

The total amount of solid waste produced in this Complex is 547.5 tons/yr. In 2004 the constituents were plastic (24.1\%), putresciable materials $(45.9 \%)$, glass (7.6\%), paper (19.3\%) and metal (3.1\%). According to the economic analysis conducted, the investment required for implementation of all the solid waste separation techniques amounts to US\$11200. The appropriate implementation of the above-mentioned techniques and selling of the separated wastes could produce an annual income of US\$13079.13, which indicates an investment return in 11 months. 
Based on these studies, new schemes for energy consumption in the administrative building and ultimately recommendations for reduction of energy consumption in the aforesaid building are provided. Although, only a portion of these energy conservation methods are mentioned here, their implementation will increase the energy efficiency of the building considerably.

According to the results of the completed questionnaires, green management checklists and the assessment of the green group, the average electricity consumption for illumination of the building and the surrounding areas, the average electricity consumption in heating and air conditioning facilities and the average water consumption in the building and the surrounding area are estimated. The result of the present investigation is indicative of a medium level of optimization for energy and water consumption in ESP and there is a high potential to improve the efficiency of the system.

Meanwhile, the results of the questionnaires distributed amongst the members and the personnel of the Complex revealed that approximately 50\% occupants were not acquainted with green management and only $30 \%$ were faintly familiar with it. The personnel's knowledge on green management was much better and about $64 \%$ of them were well acquainted with the related issues.

The importance of general and specialized training of personnel and members is quite significant in proper implementation of green management.

According to the results of the study, the following guidelines in four major topics are provided to modify and enhance the water, paper and energy consumption pattern for the improvement of the environmental status of the Complex and proper execution of green management.

As conclusion, in order to establish Green Management in such sports complexes it is necessary to create a proper environment, in which all people whether as members or employees do their best to cooperate in the preservation of all aspects of the environment. The management of a sports complex adapts itself by making necessary changes in the present organizational chart to meet such a demand.

\section{References}

[1] DOE, "Environmental Regulations and Standards", Department of the Environment Publications, 2003.

[2] Maknoun, R., "Green Government, The Experience of the Presidential Office", Bulletin No. 10, Higher Council for Protection of the Environment, Sustainable Development National Committee., 2003.

[3] Reyahi, M., "Establishment of Green Management System in Executive Institutions as an Instrument for Environmental and Economic Activities at National and International Levels in Accordance with the Objectives of the $4^{\text {th }}$ National development Plan", $5^{\text {th }}$ Bi-annual National Conference of Iranian Society of Environmentalists, 2004.

[4] DOE, "Green Government for Culture \& Sports Centers", Department of Environment Publications, $5^{\text {th }}$ Volume, 2003.

[5] www.greengovernment.com 